\title{
Audit committee chairman characteristics and corporate performance: Empirical evidence from Saudi Arabia
}

\author{
Yahya Al-Matari ${ }^{a^{*}}$
}

${ }^{a}$ King Faisal University, Saudi Arabia

\begin{tabular}{l}
\hline C H R O N I C L E \\
\hline Article history: \\
Received March 3, 2021 \\
Received in revised format May \\
112021 \\
Accepted June 52021 \\
Available online \\
June 72021 \\
\hline Keywords: \\
Corporate governance \\
Audit committee chairman \\
Cooperate performance \\
Finance sector \\
Saudi Arabia
\end{tabular}
\begin{abstract}
A B S T R A C T
The purpose of this paper is to investigate the impact of corporate governance (CG) characteristics, specifically audit committee chairman (ACC) characteristics. (tenure, expertise, and directorship) on corporate performance (CP). The study was executed on 44 firms, which were registered under the finance sector at Bursa Saudi Arabia. In terms of its scope, the study stretched over quite a long period of time and observed a considerable number of firms; more specifically, it lasted from 2015 to 2019, and observed 195 firms. The relationship between the characteristics of audit committee (AC) directors and $\mathrm{CP}$ has been studied extensively in the past. Nevertheless, few studies have investigated the ACC's characteristics. To the best of the researcher's knowledge, no study has yet studied the effect of CG's characteristics, specifically, the ACC characteristics on CP. The study's conclusions indicate that corporate governance (CG) characteristics, specifically audit committee chairman (ACC) characteristics (tenure and expertise) are positively related to the performance of finance companies. However, the audit committee chairman's multiple directorships, on the other hand, has no relationship with corporate performance. Review of literature on the audit committee chairman characteristics used in this study is offered, the practical implications and the recommendations for future research works is also emphasized.
\end{abstract}

\section{Introduction}

Considering major accounting scandals (e.g., WorldCom and Enron) and previous financial crisis, the responsibility of corporate governance, particularly the audit committee, in ensuring financial reporting integrity has been greatly empowered (Wilbanks, Hermanson, \& Sharma, 2017). Audit committees (AC) are seen as a key component of efficient corporate governance $(\mathrm{CG})$ processes and their primary role is to monitor the financial reporting process and ensure that managers ethically disclose their companies' results and to minimise information asymmetry (Al-Okaily \& Naueihed, 2020). In addition, for the financial and accounting reports examined by the members of the audit Committee to be complicated, the Directors' Experience and time spent working on the Committee involve a significant number of Directors (Sultana, 2015). The purpose of this research is to investigate the effect of the characteristics of corporate governance (CG), specifically, audit committee chairman (ACC) characteristics (tenure, expertise, and directorship), on corporate performance (CP). Previous studies found links between CP and CG mechanisms: the company's ownership arrangement, corporate social responsibility, method of audit and size of board (e.g., Pillai \& Al-Malkawi, 2018). Others also found that CP has a strong connection with financial experience and independence of the audit committee (AC) (e.g., Aldamen, Duncan, Kelly, McNamara, \& Nagel, 2012). Since CG mechanisms, such as the Board of Directors, Ownership and Audit Committee (AC)

* Corresponding author.

E-mail address: yalmatari@kfu.edu.sa (Y. Al-Matari)

(C) 2022 Growing Science Ltd. All rights reserved. doi: 10.5267/j.ac.2021.6.007 
were theoretically recommended to the agency by previous studies that they could mitigate Agency issues and improve CP (Fama \& Jensen, 1983; Jensen \& Meckling, 1976; Klein, 2002). However, the most critical question arises: how well can the AC contribute to the management of accountability and financial reporting? Xie, Davidson, and DaDalt (2003), AC could be more effective in measuring and then improving CP. As a result, there is a significant difference in managers' abilities. to follow the resolutions of the CEO, where several managers work full time in other corporate firms and are also insiders of managers and family-controlled companies, which can provide them appropriate and credible corporate information (Adams \& Ferreira, 2007). In addition, the internal and external audit roles of a three- or four-member AC will be inappropriate, since companies place full liability and pressure upon the AC (Burns, 2004). The relationship between the characteristics of AC directors and $\mathrm{CP}$ has been studied extensively in the past. Nevertheless, few studies have investigated the ACC's characteristics (Bédard \& Gendron, 2010). Hence, Carcello, Hermanson, and Ye (2011) proposed future research to investigate the impact of ACC characteristics. (e.g., attitudes, personality traits, and attributes) in improving the AC's effectiveness. The human control of the ACC has been argued to affect the organisational performance significantly (Turley \& Zaman, 2007). The Committee's conference, consultations and contact with AC representatives is to be managed by the ACC (Bédard \& Gendron, 2010). The AC includes the ACC as a member which oversees financial reporting more effectively and, in turn, is more likely than other AC members to take on responsibility for financial reporting failure (Schmidt \& Wilkins, 2013). Some AC chairpersons have held their positions for a longer tenure than a shorter tenure (Australian Securities Exchange Corporate Governance Council, 2014). As a result, the question of whether a longer ACC tenure is successful in enhancing CP has become important. Additionally, multiple AC directorships may be a major issue when the ACC is required to do much more than the AC members (Tanyi \& Smith, 2014). Therefore, where the ACC is over-committed, managers are more likely to control their companies and thus influence the CP. In terms of ACC's financial expertise, a study of Al-Absy, Ismail, and Chandren (2019) in the context of Malaysia showed no relationship with earnings management, So, the problem of ACC's competence has not been thoroughly investigated. No study has yet studied the effect of CG's characteristics, specifically, the ACC characteristics on CP, to the best of the researcher's knowledge. Therefore, by analysing their impact on CP in the context of Saudi Arabia, this study adds to the limited literature on ACC. The following sections of the study thus present the literature review, methodology and model, data analysis and results, discussion of results and finally conclusion.

\section{The hypothesis development and Previous research studies}

\subsection{Audit committee chairman's tenure}

On the directors' tenure, there are two points of view. (e.g., ACC). Firstly, long term expertise and competence in optimum activities are improved to make management decision control with regard to financial reporting options more reliable (Vafeas, 2005) Second, it is possible that more experienced managers are friends and managers are less likely to be overseen, particularly in companies by stronger CEOs (Vafeas, 2003) Long term of office will affect directors' independence in the consideration of the company's needs because they can defend the management interests in lieu of shareholders (Vafeas, 2005). Previous research has investigated the impact of tenure on financial reporting quality (FRQ). The arguments made by Chan et al. (2012) that, because of better oversight, the length of AC members' tenure would result in less auditing effort. Liu and Sun, (2010), Thoopsamut and Jaikengkit (2009), Yang and Krishnan (2005) concluded that the FRQ was higher if members of the AC had a longer term and argued that long term managers effectively oversee the mission on account of their expertise. In recent times, Herranz et al. (2018) established a nonlinear relationship to AC tenure and the consistency of financial details, stating that long-term independence of the directors can first be compromised. As for earnings management (EM), Between Shu, Yeh, Chiu, and Yang (2015), and the low level of EM, there was a connection between the tenure of the board chairman (BC) and the low level of EM, not important. Beasley (1996) however discovered an important and unfavourable relationship between the chances of false financial statements and the number of years the external directors are employed. Likewise, the tenure of the AC (average number of years served as a director) was considered favourably and strongly linked to accrual efficiency by Dhaliwal et al. (2010). Regarding corporate performance, only a few studies have investigated relation between tenure and corporate performance. For example, the relationship between $\mathrm{BC}$ tenure et performance and company performance was not substantial between Waelchli and Zeller (2013). This result is inconsistent with Livnat et al. (2021), who note that longer board tenure is associated with higher market valuations, which helps in enhancing corporate performance. Thus, and according to the above discussion, the following is the hypothesis:

\section{$\mathbf{H}_{1}$ : There is a positive relationship between the ACC's tenure and $C P$.}

\subsection{Audit Committee chairman's expertise}

The chairmanship of the AC's has a huge impact on its results. It is the duty of the ACC to ensure information flows appropriately to the committee and that It has strong relationships with other groups, such as internal and external auditors. (Bédard \& Gendron, 2010; Tanyi \& Smith, 2014). The ACC thus has the greatest duty to monitor the process of drafting a financial report as well as being more likely to be accountable than other members for any possible financial report loss (Schmidt \& Wilkins, 2013). It is mandatory, asserts the Saudi Code on Corporate Governance, that audit committee 
members should have adequate familiarity with financial issues. It is further stipulated by Corporate Governance Regulations, Chapter 2 Article 54 (a) that a minimum one member of the audit committee must be specialized in finance and accounting (Capital Market Authority (CMA), 2017). The effect of AC's experience on corporate performance has been explored in previous research. Most studies have shown a significant positive relationship, such as Aanu et al. (2014), Kipkoech \& Rono (2016) and Nuhu et al. (2017). The findings are mixed with respect to developed nations. A significantly positive correlation has emerged from Hamid and Aziz (2012), although Alqatamin (2018) has found no relevant connection. However, recent studies have not thoroughly examined the problem of the competence of ACC. Based on the agency and resource dependence hypotheses and a constructive partnership discussion, the following is a hypothesis:

\section{$\mathbf{H}_{2}$ : There is a positive relationship between the ACC's expertise and $C P$.}

\subsection{Audit Committee chairman's multiple directorships}

In CG literature, the issue of whether directors (e.g., ACC) sitting on different boards are beneficial to the company (Cashman et al., 2012; Chen et al., 2015; Elyasiani \& Zhang, 2015). The report suggests that the large number of directors lets chairs and financial experts grow their experience and knowledge, in accordance with the theories about the themes of company and resource dependency (Tanyi \& Smith, 2014). The directors with various managers are regarded as intellectual capital for companies where they are decision-makers (Beasley, 1996). Courteau (2001) showed that directors holding directorships in other companies can acquire improved governance skills. As a result, they conduct their supervision duties more efficiently which lead to more stringent management supervision that in turn increases the efficiency of financial statements. (Tanyi \& Smith, 2014). Nevertheless, the busy theory suggests that managers (e.g. ACC) that work on several boards are often engaged and evade their directorship duties as directors (Ferris, Jagannathan, and Pritchard, 2003). Alternatively, directors working in many companies cannot have the time and resources to properly monitor and provide management advice (Elyasiani \& Zhang, 2015). Excessive time demands from the ACC keep them busy and limit their ability to monitor management independence and the financial reporting process (Tanyi \& Smith, 2014). This will lead management to benefit from low supervision by chairmen and financial experts and to manipulate the companies to accomplish their own concerns instead of the needs of shareholders (Jiraporn et al., 2008, Tanyi \& Smith 2014). External executives are substantially and favourably involved in payments for CEOs, which ensures that the efficient implementation of their duties by busy directors is less competitive (Core et al., 1999). In addition, CEOs who participate in the directors' appointment process would be more likely to appoint directors who have been active in several board of directors to limit their supervisory position (Shivdasani \& Yermack, 1999). Studies on the impact of many boards of directors on earnings management are mixed. Some found good relations (Baccouche \& Omri, 2014; Baatour et al., 2017), while others found negative relations (Mansor et al., 2013) (Banderlipe, 2009; Saleh et al., 2007; Yang \& Krishnan, 2005). An analysis by Samsuri (2010) however found that there was no substantial link between an ACC with several directors in other companies and the earnings management. In the financial quality sector, there is an important and constructive relationship between fraudulent financial reports to external directors, those who retain more directorships in other companies, reducing their oversight responsibilities (Beasley, 1996). However, the consistency of financial reports is profoundly favourable for an AC of accounting professionals, independence, and less directorships (Dhaliwal et al., 2010). The partnership between ACC and other AC financial knowledge status of the ACC and the standard of financial reporting was substantially adverse for Tanyi and Smith (2014). Regarding the success of corporate performance Jiraporn et al. (2008) showed that several management companies had a strongly negative relationship to cooperate performance. (Elyasiani \& Zhang (2015) and Pombo and Gutiérrez (2011) find that multiple directorships have important positive links to cooperate performance in terms of success, according to the theories on agencies and resource dependencies. Therefore, based on the preceding argument, the following hypothesis is proposed:

$\mathbf{H}_{3}$ : There is a positive relationship between the ACC's multiple directorship and CP.

\section{Methodology and method}

\subsection{Sample selection}

As far as the target populations of the current research paper is concerned, it should be stated that all the registered Saudi companies under the finance sector represent the paper's population. It includes 44 registered companies under the finance sector, which were acquired from Saudi Stock Exchange (Tadawul). The study's sample is made up of 220 firm-year observations for 2015 to 2019 . However, owing to inadequate financial and corporate governance data, the number of firms was cut down from 44 to 39. Therefore, the study's final list of the sample encompasses 39 PLCs, and a total of 195 observations for five successive years. As for data, they were collected from the company's yearly reports as revealed on Tadawul website.

\subsection{Measures of ACC characteristics}

This paper employs tenure, competence, and several directorships to assess the impact of the ACC's employee characteristics. Importantly, although it describes these characteristics in line with the literature of previous years (Dhaliwal et al, 2010; Schmidt \& Wilkins, 2013, Sharma \& Iselin, 2012; Sharma \& Kuang, 2014; Yang \& Krsnan, 2005). Our measurements are taken at the level of individual directors rather than groups. It calculates the ACC tenure by counting the 
number of years the chairman has served on the board of directors of the focal firm. Moreover, this paper defines an ACC by accounting knowledge as a chair with skills and involvement in accounting and finance (e.g., CPA, CIA, CMA, CFO). This attribute is operationalized by assigning an $\mathrm{AC}$ to one chaired by an accounting or financial expert, otherwise null. If a directors chairman has two or three seats in other companies, and none otherwise, the ACC tests various directorships by assigning.

\subsection{Measures of corporate performance}

The present study employs ROA as the measurement of financial performance for the designated companies. Numerous preceding studies have used ROA (Al-Matari et al., 2012; Brick \& Chidambaran, 2010; Chung et al., 2002) as a measure for the performance of their firms.

\subsection{Measures of control variables}

This paper includes two sets of control variables for improving the model predictive capacity and reducing the impact of the variables skipped (Knechel \& Sharma, 2012). Firstly: corporate control and governance; including independence from AC (ACINDEP), sizes (ACSIZE), meeting (ACMEET), and accounting expertise (ACAFL). Previous literature shows that increased corporate control efficacy and governance strength involves fewer financial failures and less audit tests (Knechel et al., 2012; Sultana et al., 2015). In addition, corporate governance processes are argued and stated to be complementary or substitute (Defond et al., 2005; Brown et al., 2011). The second set of control variables is focused on the characteristics of the company (e.g., firm size, leverage, and banking sector).

\subsection{Model Specification}

The Regression Study examined the impact of ACC (tenure, financial expertise and directorship) characteristics on CP measured by ROA. CP was evaluated. The following regressions were then used for this measurement to investigate the effect of ACC characteristics on ROA. Detailed information about all variables used in this study is provided in Table 1.

$$
\begin{aligned}
& R O A=\beta_{0}+\beta_{1} A C C T E N+\beta_{2} A C C E X P+\beta_{3} A C C M D+\beta_{4} A C I N D E P+\beta_{5} A C S I Z E+\beta_{6} A C M E E T+\beta_{7} A C F A L+\beta_{8} \\
& F S I Z E+\beta_{9} L E V G E+\beta_{10} B S E C T+\varepsilon
\end{aligned}
$$

\section{Table 1}

Summary of the operationalization of the variables

\begin{tabular}{ll}
\hline Variable name & Variable measurement \\
\hline ACCTEN & The number of consecutive years the AC chair has served on a given board \\
ACCEXP & 1 if the chair of the audit committee $(\mathrm{AC})$ has qualifications and experience in accounting or finance, 0 otherwise \\
ACCMD & 1 if ACC holds two or more seats at other firms, 0 otherwise \\
ROA & Net income/total assets \\
ACINDEP & The proportion of independent directors (excluding the chair) on the AC \\
ACSIZE & The number of directors on the AC \\
ACMEET & The number of meetings held by the AC during the year \\
ACAFL & The proportion of directors (excluding the chair) with non-accounting financial expertise on the AC \\
FSIZE & The book value of the total assets of company. \\
LEVGE & The percentage of total liabilities to total assets. \\
BSECT & 1 if it is a bank, 0 otherwise. \\
\hline
\end{tabular}

\section{Data analysis and results}

\subsection{Descriptive statistics}

In the current research paper, descriptive statistics have been conducted before doing the regression analysis. According to the results of descriptive statistics displayed in Table 2, the mean of ACCTEN is 7.016. The continuous control variables' mean values are as follows: in board mechanisms, the mean values of ACINDEP, ACSIZE, ACMEET and ACFAL are 2.613, 3.026, 5.004 and 0.310, respectively; and in company-specific characteristics, the mean values of LEVGE and CSIZE are 1.913 and 281 million, respectively. Table 3 shows that 118 (60.51 percent), and 79 (40.51 percent) firm observations appointed an ACC who is an accounting specialist and holds two or more seats in other companies, individually. Table 3 also shows that 55 (28.21 percent) is banks and 140 (71.79 percent) is insurance companies. 
Table 2

Descriptive Statistics of Study Variables Measurements

\begin{tabular}{|c|c|c|c|c|c|c|c|c|}
\hline Variable & Obs & Mean & Std. Dev. & Min & Max & Skewness & Kurtosis & VIF \\
\hline ACCTEN & 195.00 & 7.016 & 5.228 & 0.488 & 15.251 & -0.411 & 2.412 & 4.031 \\
\hline ACINDEP & 195.00 & 2.613 & 0.802 & 2.000 & 5.000 & 2.140 & 5.043 & 2.023 \\
\hline ACSIZE & 195.00 & 3.026 & 0.490 & 3.000 & 5.000 & 2.542 & 9.285 & 1.144 \\
\hline ACMEET & 195.00 & 5.004 & 1.131 & 3.000 & 9.000 & 1.901 & $1 \cdot .193$ & 3.124 \\
\hline ACFAL & 195.00 & 0.310 & 1.691 & 1.000 & 3.000 & 2.881 & 3.374 & 2.661 \\
\hline ROA & 195.00 & 0.451 & 4.070 & -0.899 & 45.754 & 1.554 & 2.754 & 1.354 \\
\hline LEVGE & 195.00 & 1.913 & 0.871 & 0.667 & 5.750 & -0.650 & 6.750 & 2.630 \\
\hline *FSIZE & 195.00 & 281 & 556 & 329.873 & 3,650 & 2,450 & 4,650 & 3,420 \\
\hline
\end{tabular}

*Note: value of firms in Million

Table 3

Descriptive statistics of the dummy variables

\begin{tabular}{ccc}
\hline Variables & Frequency & Percentage \\
\hline ACCEXP & 118 & $60.51 \%$ \\
ACCMD & 79 & $40.51 \%$ \\
BSECT & 55 & $28.21 \%$ \\
\hline
\end{tabular}

\subsection{Correlation analysis}

Pearson correlation analysis was implemented to attain a knowledge of the relation amongst all the variables in the research. Table 4 illustrates that all correlations are less than the 0.90 as recommended by Hair Black, Babin and Andersen (2010); and so, there is no problem with multicollinearity or collinearity in this study. Kurtosis and skewness were both used to measure the normality of the various variables as descriptive numerical approaches. Table 2 shows that the data collection of the different variables does not really go against normality assumptions, i.e. that skewness does not generally exceed or exceed the \pm 3 threshold and the Kurtosis does not exceed the \pm 10 threshold. But only ACMEET Kurtosis is 10.193 , where this is not a significant issue (Kline, 2015). Furthermore, the Variance Inflation Factor (VIF) was used. A VIF superior to 10 shows a serious multicollinearity issue (Hair et al., 2010). However, as stated in Table 2, the values of VIF for all the variables were established to be ranged between 1.144 and 4.031 representing that the multicollinearity problem wasn't extant in this research.

Table 4

Results of Pearson Correlation Analysis

\begin{tabular}{|c|c|c|c|c|c|c|c|c|c|c|c|}
\hline Variables & 1 & 2 & 3 & 4 & 5 & 6 & 7 & 8 & 9 & 10 & 11 \\
\hline 1) ACCTEN & 1 & & & & & & & & & & \\
\hline 2) ACCEXP & -.284 & 1 & & & & & & & & & \\
\hline 3) $\mathrm{ACCMD}$ & .305 & .054 & 1 & & & & & & & & \\
\hline 4) ACINDEP & -.057 & -.174 & .062 & 1 & & & & & & & \\
\hline 5) ACSIZE & -.046 & -.112 & .002 & -.020 & 1 & & & & & & \\
\hline 6) ACMEET & .220 & -.115 & .302 & .078 & .082 & 1 & & & & & \\
\hline 7) $\mathrm{ACFAL}$ & -.136 & -.099 & .054 & -.024 & .128 & -.003 & 1 & & & & \\
\hline 8) $\mathrm{ROA}$ & .163 & -.168 & $.227 *$ & .123 & -.073 & $.646 * *$ & .046 & 1 & & & \\
\hline 9) FSIZE & $.791 *$ & -.044 & .232 & .150 & -.812 & .165 & -.129 & $.284 * *$ & 1 & & \\
\hline 10) LEVEG & $.420 * *$ & -.145 & .220 & .102 & .032 & .088 & .127 & .224 & $.519^{* *}$ & 1 & \\
\hline 11) BSECT & $.642 * *$ & -.103 & -.207 & .136 & .143 & -.086 & -.092 & -.017 & $.351 * *$ & .263 & 1 \\
\hline
\end{tabular}

Notes: ** Correlation is significant at the 0.01 level (2- tailed); * Correlation is significant at the 0.05 level (2- tail)

\subsection{Structural model}

In conclusion, with the aim of checking the hypothesized relationships of the research variables, the regression analysis was carried out. The $\mathrm{R}^{2}$ value reveals that $35.4 \%$ of the organizational output variance (ROA as proxy) is described by the model's selected independent variables, according to the results shown in Table 5 . The model's importance results with the F value obtained to be $(F=2.513, p<0.01)$ and the adjusted $\mathrm{R}^{2}$ is $19.5 \%$; the adjusted $\mathrm{R}^{2}$ expressions, to which this model is contributed by other input variables. The findings in Table 3 demonstrate that ACCTEN has a substantial positive correlation with the success of financial firms in Saudi Arabia $(\beta=0.402, t=2.601, p<0.05)$, thereby confirming Hypothesis 1 . Similarly, the findings suggest that ACCEXP has a positive correlation with the performance of finance companies in Saudi Arabia $(\beta=0.317, t=2.872, p<0.05)$, thereby confirming Hypothesis 2 . On the opposite, the findings show that ACCMD has no substantial correlation with the the performance of finance companies in Saudi Arabia $(\beta=2.305, \mathrm{t}=0.442, \mathrm{p}>0.05)$, thus hypothesis 3 is not supported. 
Table 5

The Model Results of Regression

\begin{tabular}{|c|c|c|c|c|}
\hline Variable & Coefficient & Std. Error & t-Statistic & Prob. \\
\hline ACCTEN & $0.402 *$ & 0.574 & 2.601 & 0.040 \\
\hline ACCEXP & $0.317 *$ & 0.495 & 2.872 & 0.034 \\
\hline ACCMD & 2,305 & 0.701 & 0.442 & 0.571 \\
\hline ACINDEP & $0.303 * *$ & 1.306 & 1.760 & 0.003 \\
\hline ACSIZE & 0.873 & 2.159 & 1.402 & 0.612 \\
\hline ACMEET & $-0.403 *$ & 1.405 & 1.660 & 0.046 \\
\hline ACFAL & $0.240^{*}$ & 0.970 & 1.754 & 0.039 \\
\hline FSIZE & 1.278 & 1.330 & 2.023 & 0.018 \\
\hline LEVGE & 0.146 & 0.531 & 0.530 & 0.538 \\
\hline BANKS & 3.083 & 2.342 & 2.074 & 0.026 \\
\hline R-squared & & & & 0.354 \\
\hline Adjusted R-squared & & & & 0.195 \\
\hline F-statistic & & & & 2.513 \\
\hline Prob (F-statistic) & & & & 0.001 \\
\hline
\end{tabular}

Notes: $* \mathrm{p}<0.05 ; * * \mathrm{p}<0.01$

\section{Discussion and results}

This part will address the findings of this analysis based on this results article. This research, as described earlier, is an attempt to investigate the relationship between the characteristics of $\mathrm{CG}$, namely the characteristics of ACC (tenure, experience, and multiple management) on CPs of Saudi financial companies. Table 5 provides data of a significant relationship between ACCTEN and CP, which reveals support for hypothesis H1. The findings are consistent with the relationship that exists between Livnat et al. (2021) of independent board directors and increased stock valuations, the tenure of ACC and earnings management of Al-Absy et al. (2019), the tenure of AC directors and earnings management of Yang and Krishnan (2005). Nevertheless, it contradicts the outcome of the connection between BC's tenure and Waelchli and Zeller's firm results (2013), ACC's tenure and financial reporting quality by Tanyi and Smith (2014). BC's tenure and earnings management through Shu et al. (2015). An explanatory explanation for the substantive outcome of the recent study is that as required by the SCCG, the ACC is an Independent Director. Therefore, we see that the long-term ACC can reduce the problem of information asymmetry and lead to improved CP. About ACCEXP, the findings of this analysis show a positive association between ACCEXP and the CP of Saudi Arabia's finance firms, which reveals support for the H2 hypothesis. This result confirms the opinion that audit committees with financial experience are less likely to participate in false financial reporting (Farber, 2005) and restatements of earnings (Abbott et al., 2004; Agrawal \& Chadwa, 2005) and are more likely to provide reports on predictions (Karamanou \& Vafeas, 2005). The outcome is consistent with several studies that have found a substantially positive correlation between financial knowledge from AC and CP (Aanu et al., 2014; Hamid \& Aziz, 2012; Kipkoech \& Rono, 2016; Nuhu et al., 2017). It is, however, inconsistent with studies that have found no significant connection between AC financial expertise and CP (Alqatamin, 2018), AC financial expertise and earnings management (Abdul-Rahman \& Ali, 2006; Ishak, Haron, Salleh, and Rashid, 2011; Mansor et al., 2013; Saleh et al., 2007). Finally, this study found that the ACCMD has no relationship to the CP of Saudi Arabia's financing firms, which means it rejects the $\mathrm{H} 3$ hypothesis. The findings show a substantially positive relationship between different directorships and CP (Elyasiani \& Zhang, 2015 and Pombo and Gutiérrez, 2011) were inconsistent. It also contradicts research conducted by Jiraporn et al. (2008) and Saleh et al. (2007) and Chandren, Ahmad and Ali (2015) which found a clear negative link between various directors and the $\mathrm{Cp}$, who found substantial negative connections between multiple directorships and earning management. However, according to Samsuri (2010), who has not found a critical relationship between the ACC and several directors and managers. The results illustrate the theory that directors of different managers (e.g. ACCs) are over-committed in shirking their duties as directors (Ferris et al., 2003).

\section{Conclusion}

The responsibility of the AC in global governance reforms has been increased from time to time. Most of those governance regulators in the world require Corporate Boards, each of which must be independent directors, plus their chairman, to form an $\mathrm{AC}$ of at least three members that have no executive officers. In addition, all AC members should be "financially literate" with at least one having accounting experience. in accounting. Nevertheless, some authorities expect the ACC to be an accounts, finance, and audit specialist, for example Germany, Spain, and Singapore. The effect of ACC (tenure, accounting expertise and directorship) on CP was discussed in this study. The findings showed that the CP's increased CP is correlated with ACC tenure and the experienced ACC in Accounting or Finance, while the CP's are not associated with several ACC directors. The findings add to the literature and the understanding of the effect of ACC attributes, such as tenure and experience, by demonstrating the correlation and increased performance of these variables. The Board and the management of organizations can use the results to make appropriate choices about ACC characteristics and governance structures to enhance efficiency, especially in terms of tenure and expertise. Shareholders can find the facts useful in knowing Saudi finance firms in terms of their governance and in making effective investment decisions. It also helps policy makers with a clearer understanding of the features of ACC that could be integrated into future policy formulation to preserve shareholder 
investment, secure the interests of the different stakeholders, and improve the movement of capital and foreign direct investment to finance companies and the economy. Findings may be helpful for regulators in other jurisdictions that are looking at ways to boost the efficiency of ACC, company governance and increase investor trust in companies. The findings also contribute through its explanation of the underpinning theories (agency theory and resource dependence theory) in providing insights into the performance of finance companies in the Saudi context. This paper has its own limitations, with the first being that its scope is limited to examine this relationship in finance companies among Saudi listed firms. Further studies may focus on another context. This study is also limited in confining some of the characteristics of ACC (tenure, expertise, multiple directors), future works can be dedicated to examining other characteristics such as age, gender and ethnicity. The paper is also limited in its use of ROA as a proxy for the performance of finance companies. Future studies can use different accounting measures and market measures that can provide a more comprehensive insight into corporate performance.

\section{Acknowledgments}

The author acknowledges the Deanship of scientific Research at King Faisal University for the financial support under Nasher Track (Grant No. 206036).

\section{References}

Aanu, O. S., Odianonsen, I. F., \& Foyeke, O. I. (2014). Effectiveness of audit committee and firm financial performance in Nigeria: An empirical analysis. Journal of Accounting and Auditing: Research and Practice, 1-12. [Online Journal] Retrieved from http://eprints.covenantuniversity.edu.ng/id/eprint/7208.

Abbott, L. J., Parker, S., \& Peters, G. F. (2004). Audit committee characteristics and restatements. A Journal of Practice \& Theory, 23(1), 69-87.

Abdul Rahman, R., \& Haneem Mohamed Ali, F. (2006). Board, audit committee, culture and earnings management: Malaysian evidence. Managerial Auditing Journal, 21(7), 783-804.

Adams, R.B., \& Ferreira, D. (2007). A theory of friendly boards. The Journal of Finance, 62(1), 217-250.

Agrawal, A. \& Chadwa, S. (2005). Corporate Governance and Accounting Scandal". Journal of Law and Economics, 48(1), 371-406.

Al-Absy, M. S. M., Ismail, K. N. I. K., \& Chandren, S. (2019). Audit committee chairman characteristics and earnings management. Asia-Pacific Journal of Business Administration, 11(4), 339-370.

Aldamen, H., Duncan, K., Kelly, S., McNamara, R. and Nagel, S. (2012). Audit committee characteristics and firm performance during the global financial crisis. Accounting and Finance, 52(4), 971-1000.

Al-Matari, Y. A., Al-Swidi, A. K., Fadzil, F. H. B., \& Al-Matari, E. M. (2012). Board of Directors, Audit Committee Characteristics and the Performance of Saudi Arabia Listed Companies. International Review of Management and Marketing, 2(4), 241-251.

Al-Okaily, J., \& Naueihed, S. (2019). Audit committee effectiveness and family firms: impact on performance. Management Decision, 58(6), 1021- 1034.

Alqatamin, R. M. (2018). Audit committee effectiveness and company performance. Accounting and Finance Research, $7(2), 48-60$.

Australian Securities Exchange Corporate Governance Council (2014), Corporate governance principles and recommendations. Australian Securities Exchange, Sydney, available at: www.asx.com.au/documents/asxcompliance/cgc-principles-and-recommendations-3rd-edn.pdf.

Baatour, K., Othman, H. B., \& Hussainey, K. (2017). The effect of multiple directorships on real and accrual-based earnings management. Accounting Research Journal, 30(4), 395-412.

Baccouche, S., \& Omri, A. (2014). Multiple directorships of board members and earnings management: an empirical evidence from French listed companies. Journal of Economic and Financial Modelling, 2(1), 13-23.

Banderlipe, M.S. (2009), "The impact of selected corporate governance variables in mitigating earnings management in the Philippines", DLSU Business \& Economics Review, 19(1), 17-27.

Baxter, P., \& Cotter, J. (2009). Audit committees and earnings quality. Accounting \& Finance, 49(2), 267-290.

Beasley, M. (1996). An empirical analysis of the relation between the board of director composition and financial statement fraud. Accounting Review, 71(4), 443-465.

Bédard, J., \& Gendron, Y. (2010). Strengthening the financial reporting system: can audit committees deliver?. International Journal of Auditing, 14(2), 174-210.

Brick, I. E., \& Chidambaran, N. K. (2010). Board meetings, committee structure, and firm value. Journal of Corporate Finance, 16(4), 533-553.

Brown, P., Beekes, W. and Verhoeven, P. (2011). Corporate governance, accounting and finance: a review", Accounting \& Finance, 51(1), 96-172.

Burns, J. (2004). Is Sarbanes-Oxley working? We asked a variety of experts; most of them said yes — with some caveats. Wall Street Journal, June, available at: http://online.wsj.com/ad/article/ ironmountain/SB108750495035740487.html

Capital Market Authority (2017). The code of corporate governance in the Kingdom of Saudi Arabia. Retrieved August 20, 2020, from https://cma.org.sa/en/RulesRegulations/Regulations/Documents/CGRegulations_en.pdf 
Carcello, J.V., Hermanson, D.R., \& Ye, Z. (2011). Corporate governance research in accounting and auditing: insights, practice implications, and future research directions. Auditing: A Journal of Practice \& Theory, 30(3), 1-31.

Cashman, G.D., Gillan, S.L., \& Jun, C. (2012). Going overboard? On busy directors and firm value. Journal of Banking \& Finance, 36(12), 3248-3259.

Chan, A. M. Y., Liu, G., \& Sun, J. (2012). Independent audit committee members ' board tenure and audit fees. Accounting \& Finance, 53(4), 1129-1147.

Chan, K., \& Li, J. (2008). Audit committee and firm value: evidence on outside top executives as expert independent directors. Corporate Governance: An International Review, 16(1), 16-31.

Chandren, S., Ahmad, Z. and Ali, R. (2015), "Corporate governance mechanisms and accretive share buyback to meet or beat earnings per share forecast", International Journal of Business and Society, 16(3), 344-363.

Chen, L.-Y., Lai, J.-H., \& Chen, C.R. (2015). Multiple directorships and the performance of mergers \& acquisitions. The North American Journal of Economics and Finance, 33(1), 178-198.

Courteau, L. (2001), "Corporate governance and earnings management”, working paper, University Laval, Québec.

Chung, D. S., Kim, B. G., Kim, D. W., \& Choi, S. (2008). Corporate governance and firm perfroamnce: the Korea evidence. Journal of International Business and Economic, 8(2), 46-54.

Core, J.E., Holthausen, R.W. and Larcker, D.F. (1999), "Corporate governance, chief executive officer compensation, and firm performance", Journal of Financial Economics, 51(3), 371-406.

Defond, M. L., Hann R. N., \& Hu, X. (2005). Does the market value financial expertise on audit committees of boards of directors? Journal of Accounting Research, 43(1), 153-193.

Dhaliwal, D., Naiker, V., \& Navissi, F. (2010). The association between accruals quality and the characteristics of accounting experts and mix of expertise on audit committees. Contemporary Accounting Research, 27(3), $787-827$.

Elyasiani, E., \& Zhang, L. (2015). Bank holding company performance, risk, and 'busy' board of directors. Journal of Banking \& Finance, 60(1), 239-251.

Fama, E., \& Jensen, M. (1983). Agency problems and residual claims. The Journal of Law and Economics, 26(2), $327-349$.

Farber, D. (2005). Restoring trust after fraud: does corporate governance matter?. The Accounting Review, 80(2), 539-561.

Ferris, S.P., Jagannathan, M., \& Pritchard, A.C. (2003). Too busy to mind the business? Monitoring by directors with multiple board appointments. The Journal of Finance, 58(3), 1087-1111.

Hair, J.F Jr., Black, W.C., Babin, B.J., \& Andersen, R.E. (2010). Multivariate Data Analysis. $7^{\text {th }}$ ed. Upper Saddle River, NJ: Pearson Prentice Hall.

Hamid, A., \& Aziz, R. (2012). Impact of the amendments of Malaysian code of corporate governance (2007) on governance of GLCs and performance. World Academy of Science, Engineering and Technology, 6(11), 612-617.

Herranz, C. Z., Iturriaga, F. J. L., \& Reguera-Alvarado, N. (2018). The right person at the right time: Audit committee members and the quality of financial information. Universia Busines Review, 58, 18-35.

Ishak, I., Haron, M.N., Salleh, N., \& Rashid, A.A. (2011). Family control and earnings management: Malaysia evidence. 2nd International Conference on Economics, Business and Management Ipedr, 22@ Iacsit Press, Singapore, 22, 82-86.

Jensen, M. C., \& Meckling, W. H. (1976). Theory of the firm: Managerial behavior, agency costs and ownership structure. Journal of Financial Economics, 3(4), 305-360.

Jiraporn, P., Kim, Y.S., \& Davidson, W.N. (2008). Multiple directorships and corporate diversification. Journal of Empirical Finance, 15(3), 418-435.

Kipkoech, S. R., \& Rono, L. (2016). Audit committee size, experience and firm financial performance. Evidence Nairobi Securities Exchange, Kenya. Research Journal of Finance and Accounting, 7(15), 87-95.

Klein, A. (2002). Audit committee, board of director characteristics and earnings management. Journal of Accounting and Economics, 33(1), 375-400.

Kline, R.B. (2015), Principles and Practice of Structural Equation Modeling, $4^{\text {th }}$ ed., Guilford Publications, New York, NY and London.

Knechel, W. R., \& Sharma, D. S. (2012). Auditor-provided nonaudit services and audit effectiveness and efficiency: Evidence from pre-and post-SOX audit report lags. Auditing: A Journal of Practice \& Theory, 31(4), 85-114.

Knechel, W.R., Sharma, D.S., \& Sharma, V.D. (2012), "Non-audit services and knowledge spillovers: evidence from New Zealand", Journal of Business Finance \& Accounting, 39(1), 60-81.

Liu, G., \& Sun, J. (2010). Director tenure and independent audit committee effectiveness. International Research Journal of Finance \& Economics, 51, 176-189.

Livnat, J., Smith, G., Suslava, K., \& Tarlie, M. (2021). Board tenure and firm performance. Global Finance Journal, 47, 100535.

Mansor, N., Che-Ahmad, A., Ahmad-Zaluki, N., \& Osman, A. (2013). Corporate governance and earnings management: a study on the Malaysian family and non-family owned PLCs. Procedia Economics and Finance, 7, 221-229.

Nuhu, M. S., Umaru, S. Y., \& Salisu, S. (2017). The effect of audit committee's quality on the financial performance of food and beverages industry in Nigeria. International Journal of Business and Management Invention, 6(9), $32-40$.

Pillai, R., \& Al-Malkawi, H. (2018). On the relationship between corporate governance and firm performance: evidence from GCC countries. Research in International Business and Finance, 44(4), 394-410.

Pombo, C., \& Gutiérrez, L.H. (2011). Outside directors, board interlocks and firm performance: empirical evidence from Colombian business groups. Journal of Economics and Business, 63(4),251-277. 
Saleh, N.M., Iskandar, T.M., \& Rahmat, M.M. (2007). Audit committee characteristics and earnings management: evidence from Malaysia", Asian Review of Accounting, 15(2),147-163.

Samsuri, A.S. (2010). Earnings management in Malaysia: the role of audit committee chairman", unpublished thesis in business administration (Accounting), (master's thesis), Universiti Utara Malaysia, Kedah.

Schmidt, J., \& Wilkins, M.S. (2013). Bringing darkness to light: The influence of auditor quality and audit committee expertise on the timeliness of financial statement restatement disclosures. Auditing: A Journal of Practice \& Theory, $32(1), 221-244$.

Sharma, V. D., \& Iselin, E. R. (2012). The association between audit committee multiple-directorships, tenure, and financial misstatements. Auditing: A Journal of Practice \& Theory, 31(3), 149-175.

Sharma, V. D., \& Kuang, C. (2014). Voluntary Audit Committee Characteristics, Incentives, and Aggressive Earnings Management: Evidence from New Zealand. International Journal of Auditing, 18(1),76-89.

Shivdasani, A., \& Yermack, D. (1999). CEO involvement in the selection of new board members: an empirical analysis. The Journal of Finance, 54(5),1829-1853.

Shu, P.-G., Yeh, Y.-H., Chiu, S.-B., \& Yang, Y.-W. (2015). Board external connectedness and earnings management. Asia Pacific Management Review, 20(4),265-274.

Sultana, N. (2015). Audit committee characteristics and accounting conservatism. International Journal of Auditing, $19(2), 88-102$.

Sultana, N., Singh, H., \& Van der Zahn, J.-L.W.M. (2015). Audit committee characteristics and audit report lag. International Journal of Auditing, 19(1),72-87.

Tanyi, P.N., \& Smith, D.B. (2014). Busyness, expertise, and financial reporting quality of audit committee chairs and financial experts. Auditing: A Journal of Practice \& Theory, 34(2),59-89.

Thoopsamut, W., \& Jaikengkit, A. (2009). Audit committee characteristics, audit firm size and quarterly earnings management in Thailand. In Emerging Issues and Challenges in Business \& Economics: Selected Contributions from the 8th Global Conference, Firenze University Press, 24,47

Turley, S., \& Zaman, M. (2007). Audit committee effectiveness: informal processes and behavioural effects. Accounting, Auditing \& Accountability Journal, 20(5),765-788.

Vafeas, N. (2003). Length of board tenure and outside director independence. Journal of Business Finance \& Accounting, 30(7-8), 1043-1064.

Vafeas, N. (2005). Audit committees, boards, and the quality of reported earnings. Contemporary accounting research, 22(4), 1093-1122.

Waelchli, U. and Zeller, J. (2013). Old captains at the helm: chairman age and firm performance. Journal of Banking \& Finance, 37(5),1612-1628.

Wilbanks, R. M., Hermanson, D. R., \& Sharma, V. D. (2017). Audit committee oversight of fraud risk: The role of social ties, professional ties, and governance characteristics. Accounting Horizons, 31(3), 21-38.

Xie, B., Davidson III, W. N., \& DaDalt, P. J. (2003). Earnings management and corporate governance: the role of the board and the audit committee. Journal of corporate finance, 9(3), 295-316.

Yang, J.S., \& Krishnan, J. (2005). Audit committees and quarterly earnings management. International Journal of Auditing, 9(3), 201-219. 


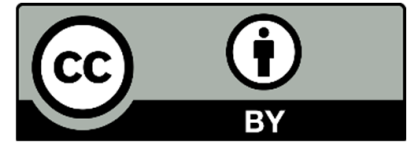

(C) 2022 by the authors; licensee Growing Science, Canada. This is an open access article distributed under the terms and conditions of the Creative Commons Attribution (CC-BY) license (http://creativecommons.org/licenses/by/4.0/). 